\title{
O PARQUE CAPIBARIBE NO RECIFE: UMA ANÁLISE ENTRE VULNERABILIDADE SOCIAL E INTEGRAÇÃO SOCIOESPACIAL DOS ESPAÇOS PÚBLICOS VERDES NAS MARGENS DO RIO
}

\author{
THE CAPIBARIBE PARK IN RECIFE: AN ANALYSIS BETWEEN SOCIAL VULNERABILITY AND \\ SOCIO-SPATIAL INTEGRATION OF GREEN PUBLIC SPACES ON THE RIVER BANKS
}

\author{
Anna Karina Borges de ALENCAR ${ }^{1}$ \\ Werther Lima Ferraz de SÁ2
}

Palavras-chave: Parque Capibaribe; Rio Capibaribe; Integrador Socioespacial; Assentamentos Precários; Sintaxe Espacial.

\section{Keywords:} Capibaribe Park; Capibaribe River; Socio-spatial Integrator; Slums; Spatial Syntax.

\section{R E S U M O}

0 rio Capibaribe é um dos elementos de maior força na estruturação urbana do Recife, pois percorre boa parte do seu território, estabelecendo barreiras e conexões entre bairros e regiões. Este artigo tem o objetivo de analisar as relações socioespaciais da área de entorno do rio Capibaribe na cidade do Recife, avaliando especialmente o potencial do tecido urbano nas áreas próximas ao rio, assim como, as diferenças e contrastes socioeconômicos da população que vive nesse território. Para desenvolver este estudo, além das visitas de campo, foram utilizados instrumentos urbanísticos para analisar o território urbano sob diferentes enfoques buscando identificar e entender as diferenças socioespaciais, assim como a fragmentação / segregação presente na área em estudo. Por meio das análises, como parte do escopo do Plano Urbanístico e de Resgate Ambiental do Capibaribe - PURA Capibaribe ${ }^{3}$, que tem como premissa apontar o potencial das intervenções urbanísticas para promover a articulação e integração socioespacial no entorno do rio Capibaribe, especialmente na região denominada de "Zona Parque" 4.

\section{A B S T R A C T}

The Capibaribe river is one of the elements of greater strength in the urban structure of Recife, since it crosses much of its territory, establishing barriers and connections between neighborhoods and regions. This article aims to analyze the social and spatial relationships of the surrounding area of the Capibaribe river in the city of Recife, especially evaluating the potential of the urban fabric in areas near the river, as well as the socioeconomic differences and contrasts of the population living in this territory. To develop this study, in addition to the field visits, urbanistic tools were used to analyze the urban territory under different approaches to identify and understand socio-spatial differences, as well as the fragmentation / segregation present in the study area. Through the analyzes, as part of the scope of the Capibaribe Urban Planning and Environmental Rescue Plan - PURA Capibaribe, it is aimed at pointing out the potential of urban interventions to promote socio-spatial integration and integration around the Capibaribe river, especially in the region known as the "Zona Park".

\footnotetext{
1 Profa. Substituta no Departamento de Arquitetura e Urbanismo - UFPE. Pós-Doc em Planejamento e Gestão Urbana e Regional MDU / UFPE- Brasil. Pesquisadora no INCITI / UFPE - Pesquisa e Inovação para as cidades. E-mail: anna.alencar@gmail.com.

${ }^{2}$ Professor de arquitetura e urbanismo na Faculdade Guararapes - Recife - Brasil. E-mail: wertherferraz@gmail.com.

3 Este artigo constitui um recorte do PURA Capibaribe - Plano Urbanístico e de Resgate Ambiental do Capibaribe, que integra os produtos relativos ao Projeto do Parque Capibaribe.

${ }^{4}$ Zona de influência direta do Parque Capibaribe sobre o território do Recife.
} 


\section{INTRODUÇÃO}

0 presente artigo traz à tona a pesquisa realizada pela equipe do Projeto Parque Capibaribe5, acerca das relações socioespaciais próximas aos cursos d'água banhados pela bacia do rio Capibaribe no território da cidade do Recife, avaliando especialmente o potencial do tecido urbano no entorno deste rio. 0 propósito inicial desta análise é apontar soluções urbanísticas de forma a apoiar no processo de transformação da relação entre cidade e o rio trazendo elementos que contribuam para a integração socioespacial da cidade do Recife.

No Recife, o padrão de ocupação, decorrente da sua formação política, econômica e social e dos condicionantes geormofológicos (alagados, morros etc.), evidencia uma aproximação geográfica entre setores socialmente muito distantes e com condições de habitabilidade significativamente desiguais. Os morros e alagados, inicialmente não cobiçados pelo mercado imobiliário, foram os locais onde a população de baixa renda encontrou uma alternativa e possibilidade de moradia. Entretanto, importante ressaltar que as faixas marginais de rios no Recife, assim como em grande parte das cidades brasileiras, além de serem ocupadas pela população de baixa renda, vêm dando lugar a empreendimentos imobiliários de média e alta renda, imóveis públicos, assim como a vias marginais expressas para veículos motorizados, em detrimento da criação de espaços públicos que promovam a integração social.

Os instrumentos usados para analisar o território no entorno do rio Capibaribe estão inseridos nos seguintes tipos de abordagem aqui desenvolvidas: 1. Mapeamento e análise dos assentamentos precários no entorno do rio, segundo delimitações da legislação municipal (as ZEIS), do IBGE (Aglomerados subnormais) e da pesquisa de Campo (em Assentamentos Ribeirinhos Críticos); 2. Elaboração e mapeamento da síntese sobre os Indicadores de Vulnerabilidade Social - IDV, no município do Recife; e 3. Análise dos níveis de integração e segregação dos espaços urbanos através dos instrumentos de sintaxe espacial;

Cada uma destas análises forneceu uma leitura específica sobre o território, as quais buscou-se interpretar de forma integrada, e confrontando com o conhecimento empírico sobre este território, construído na vivência cotidiana e nas visitas de campo realizadas pela equipe de trabalho. Antes de apresentar o conteúdo detalhado destas análises, é pertinente discorrer algumas considerações sobre o papel do rio Capibaribe como estruturador do território, assim como, sobre o panorama de integração e segregação socioespacial observadas nas áreas de influência do Parque Capibaribe, que foram identificadas ao longo das visitas e estudos para elaboração do PURA Capibaribe.

\section{RIO CAPIBARIBE COMO ESTRUTURADOR E SEGREGADOR DO TERRITÓRIO DO RECIFE}

\footnotetext{
${ }^{5}$ Este projeto é fruto do convênio técnico firmado em setembro de 2013 entre Prefeitura da Cidade do Recife - PCR e a Universidade Federal de Pernambuco - UFPE representado pelo grupo de Pesquisa e Inovação para a Cidade - INCITI / UFPE, propondo o "Plano Urbanístico de Resgate Ambiental do rio Capibaribe - PURA Capibaribe" (PARQUE CAPIBARIBE / INCITI, 2014, p5).
} 
A cidade do Recife é um dos grandes centros metropolitanos do Brasil, ocupa uma área de $218 \mathrm{~km}^{2}$, inserido na Região Metropolitana do Recife, sendo esta a $9^{\circ}$ cidade mais populosa do país com 1.625.583 habitantes (estimativa do IBGE, 2017). Apesar da porção da bacia do rio Capibaribe, inserida nos limites da cidade do Recife ser apenas de 7,58\% da área de drenagem total, no Recife, esse rio tem uma grande importância desde o seu processo de formação. A área que hoje corresponde à cidade do Recife, desde sua origem, é exemplo emblemático do embate histórico entre cidade e seus rios. Seu território se formou a partir da deposição de sedimentos numa antiga baía rasa onde deságuam os dois mais importantes rios da região: o Capibaribe e o Beberibe, além de outros de menor porte, como o Tejipió, Jiquiá e Jordão (Figura 01).

Figura 01. Rede Hídrica do rio Capibaribe.

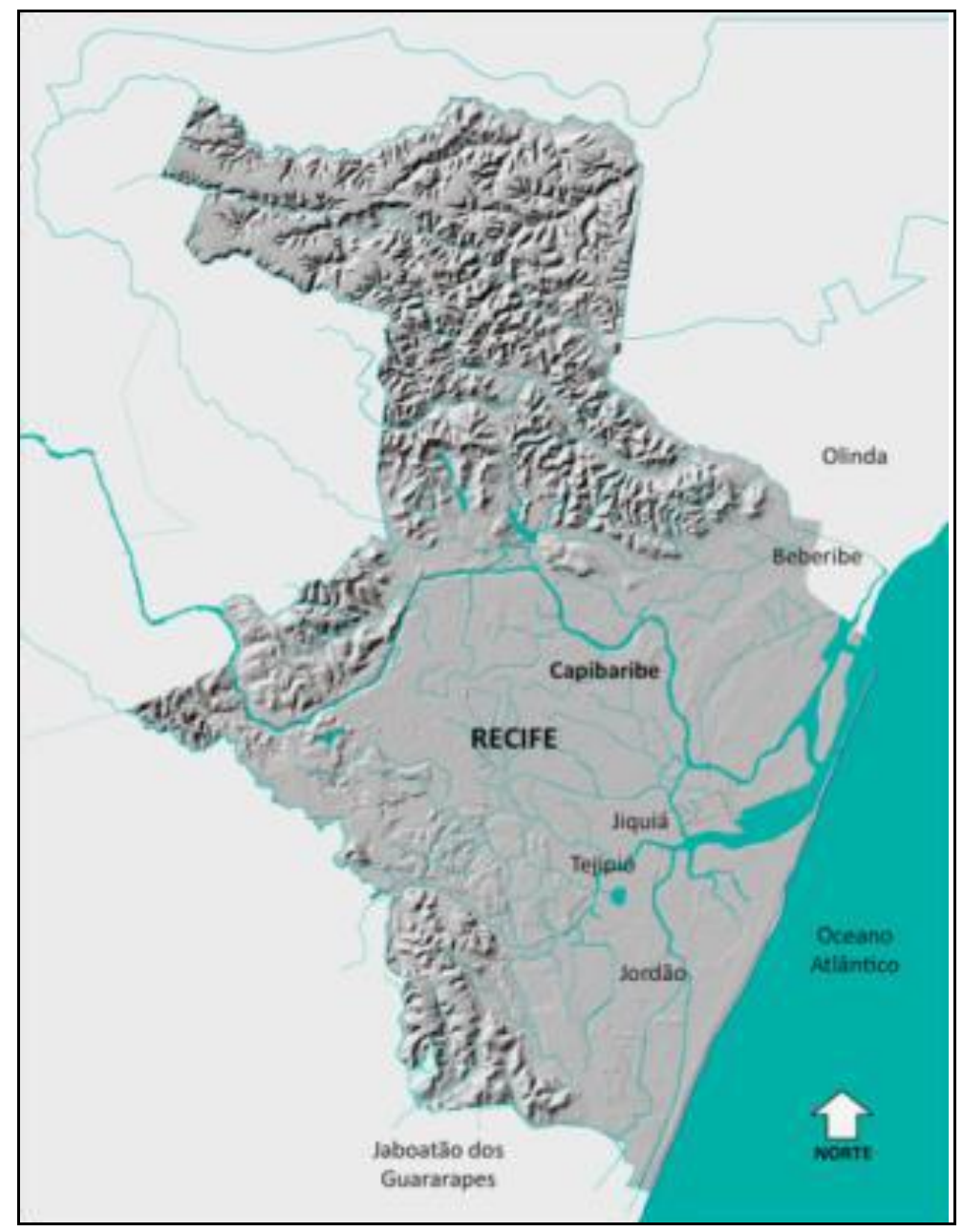

Fonte: INCITI, no prelo. (Elaborado em 2014)

Entre os séculos XVII e XVIII, a morfologia do rio Capibaribe direcionou o processo de ocupação da cidade, que foi realizado acompanhando as sinuosidades do rio, (como demonstrado na Figura 02) desde o porto em direção à ilha de Antônio Vaz, assim como no sentido Leste-Oeste da 
cidade, onde estavam localizados os engenhos de açúcar, nas "várzeas do Capibaribe". Como destaca Castro (1948), a presença das águas definia os caminhos da expansão da cidade.

Figura 02: Segmento do mapa de divisão dos bairros cortados pelo rio Capibaribe.

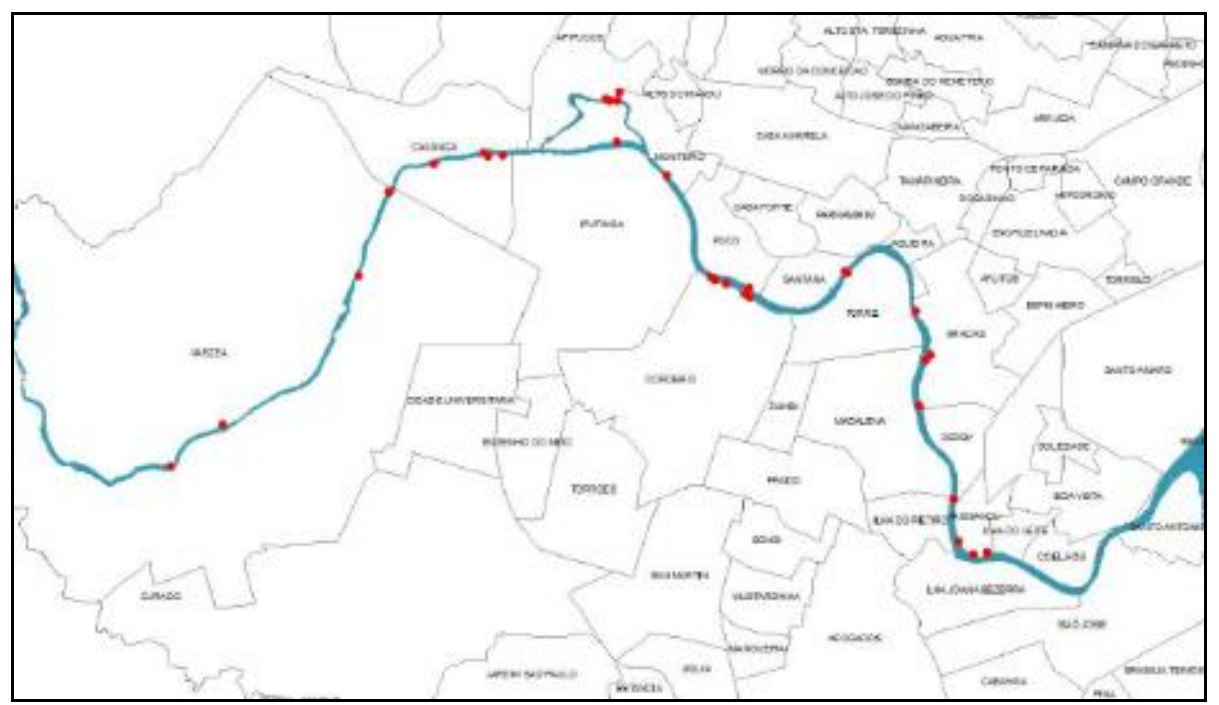

Fonte: INCITI, no prelo. (Elaborado em 2014)

No final do século XVIII com a expansão da cidade, foi se iniciando o desmembramento dos antigos engenhos os transformando, pouco a pouco, em chácaras, sítios e pomares ao longo do rio Capibaribe. Os poucos engenhos que passaram por esta transformação estavam situados na margem esquerda do rio, pois a dificuldade de vias de acesso à outra margem retardou o processo de crescimento do povoado nesta margem, a da direita, que até então só se acessava por travessia de barcos pela margem esquerda, que já possuía estradas de terra. Assim, o rio Capibaribe tanto serviu de referência inicial no processo de expansão da cidade como também se impôs como limite para o crescimento da cidade até o final do século XVIII.

Naquela época, diversos casarios ilustres de bairros como a Madalena, foram edificados com a frente para o rio, com um cais de atracamento, possibilitando usufruir das águas do rio Capibaribe. Entretanto, no início do século XX em meio ao processo de modernização da cidade com a abertura de vias internas, as casas começaram a dar as costas ao rio, contribuindo com o processo de desvalorização das margens do rio Capibaribe. Junto ao processo dos casarios darem as costas ao rio, os escravos libertos começaram a ocupar espontaneamente as margens do rio construindo seus mocambos 6 à beira dos manguezais, em locais sem nenhuma infraestrutura como destaca Castro (1948, p 260). "Quando o caboclo chega do interior para a cidade, a única maneira de abrigar a família é no mangue, no mangue não se paga casa, come-se caranguejo e anda-se quase nu (...) No mangue o terreno não é de ninguém, é

${ }^{6}$ Habitações bastante precárias construídas com restos de madeira pela população de baixa renda nas áreas alagadas do Recife. 
da maré". Assim, os assentamentos precários ${ }^{7}$ foram se distribuindo por todo o território do Recife, em espacial, os morros e alagados, locais onde a população de baixa renda encontrou como uma alternativa e uma possibilidade de moradia.

As áreas que margeiam o rio Capibaribe, desde a década de 1970, foram elementos em evidência nas discussões municipais, por causa da cheia de 1975, considerada a maior catástrofe ocorrida naquele século. Diante desta catástrofe foram formulados vários planos e projetos com intenção de controlar o rio Capibaribe. As várias inundações que ocorreram na década de 1970 causaram vários danos, destruindo habitações, pontes, comércios, industrias e etc. Além das obras de controle do rio, como construção de barragens e retificações de alguns trechos do rio Capibaribe, com o intuito de resgatar os espaços próximos ao rio destruídos pelas inundações, diversos programas e projetos propostos pelos governos estadual e municipal foram elaborados.

Em meio aos vários projetos a prefeitura elaborou um programa de revitalização das margens do rio - "Projeto Recife", que tinha como objetivo principal elevar a renda monetária das famílias mais pobres que residiam nas margens do rio Capibaribe, bem como preservar as áreas verdes e naturais (PROJETO RECIFE, 1979). Entretanto, Lima (2005) aponta que o "Projeto Recife" seguia a mesma lógica de planejamento urbano em vigor à época: a remoção de assentamentos precários das áreas mais valorizadas da cidade, reassentando-os nas áreas de menor valor imobiliário. Segundo a autora, a ideia era vender a terra de maior valor no mercado para, com esse recurso, urbanizar outras ainda não tanto procuradas, a margem direita do rio.

Ao analisar os projetos urbanísticos que envolveram o rio Capibaribe, o que se percebeu é que apesar das várias propostas com vista em melhorar o rio Capibaribe e as áreas do seu entorno, considerável parte delas não se concretizou, e as que foram implantadas, ainda predominaram as soluções de construção de vias nas faixas marginais; e obras de canalização e retificações de leitos com vista na contenção de inundações e estruturação do sistema viário, em detrimento da recuperação e valorização dos cursos de água urbanos. Tal modelo de construção de faixas marginais que privilegiam o veículo motorizado, ampliando os espaços de circulação para os carros e não para as pessoas atenuou o processo de gentrificação da população de baixa renda com as ações centrada na remoção dessa população.

Vale ressaltar também que muitas das intervenções foram realizadas em terras públicas ${ }^{8}$, resultantes dos projetos anteriores de grande porte, como a ampliação e retificação da calha do Capibaribe realizada entre as décadas de 1970 e 1980. Na década de 1990 ainda se viu a construção de faixas marginais com remoção da população de baixa renda desenvolvido pelo Projeto Beira Rio nos

\footnotetext{
7 De acordo com levantamento do Observatório das Metrópoles do Recife, no ano de 2000, 57,33\% da população vivia em áreas precárias distribuídas por todo o território da cidade.

${ }^{8}$ As terras públicas remanescentes das retificações do rio nas décadas de 1970 e 1980 foram utilizadas em conjuntos habitacionais na margem esquerda, como Detran, Airton Senna, Vila Santa Luzia e Casarão do Cordeiro, e mais recentemente no Casarão do Barbalho; mas também para Parques Públicos como Caiara e Santana.
} 
bairros da Madalena, Torre, Casa Forte que tinha como objetivo ligar diretamente 21 bairros da cidade (desde a BR 101 até o centro da cidade - Ponte Velha) com vias marginais para veículos motorizados.

Observando a configuração urbanística no entorno do rio (na Figura 03 a seguir) pode-se constatar que trechos importantes do seu percurso urbano ainda permanecem sem travessias efetivas entre as margens, apesar da alta densidade populacional existente. Sobre esse aspecto, destaca-se especialmente o trecho entre a ponte do Vintém (Torre / Parnamirim) e a ponte da rodovia BR 101, que possui quase $5 \mathrm{Km}$ de distância, mas nenhuma travessia de veículos. Existem apenas duas travessias de pedestres nesse trecho, mas com graves restrições para sua utilização. Para efeito de comparação, pode-se observar o trecho situado a jusante deste, entre a mesma ponte do Vintém e a foz do Capibaribe no bairro do Recife, que possui pouco mais de $8 \mathrm{~km}$, e um total de 13 pontes bem conectadas ao tecido urbano.

Figura 03: Mapa Análise Sintática de Integração / desintegração entre bairros.

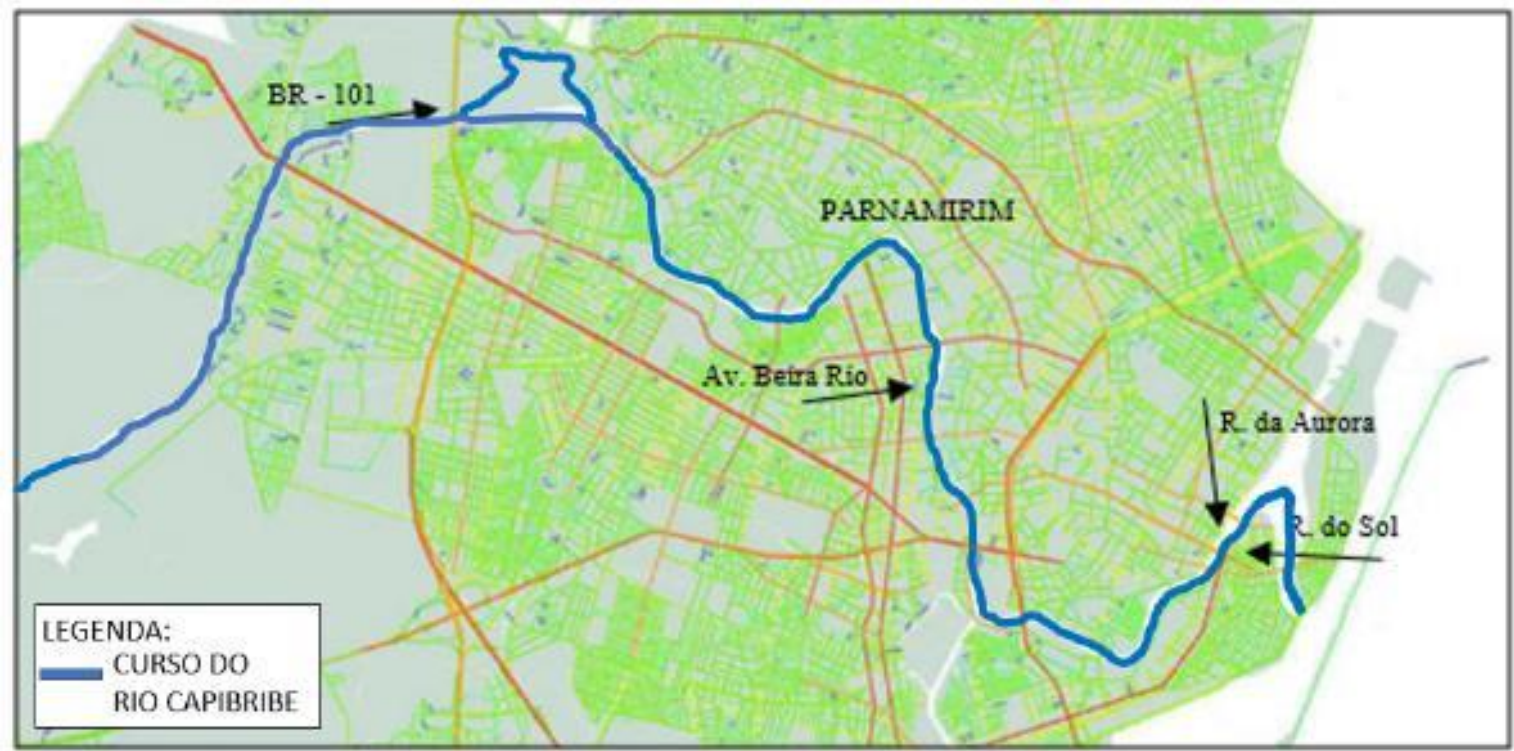

Fonte: INCITI, no prelo. (Elaborado em 2015)

Por outro lado, ao buscar referências positivas sobre o uso das margens urbanas do Capibaribe como espaços de lazer e convivência integrados ao tecido urbano, pode-se afirmar que apenas dois trechos apresentam características que os destacam como espaços urbanos qualificados para valorizar a relação da cidade com o rio. Trata-se dos trechos que envolvem a rua da Aurora e rua do Sol na região central da cidade; e o trecho da Avenida Beira Rio, no Bairro da Madalena. Não por acaso, estes são os trechos de tecido urbano que apresentam maior nível de integração espacial, segundo a análise com os instrumentos da sintaxe espacial (demonstrado na Figura 03). Na verdade, estes também são trechos onde o tecido urbano da cidade está melhor "arrematado" nas margens do Capibaribe, onde há vias que percorrem as margens e estão bem conectados com o tecido urbano do entorno. 


\section{ASSENTAMENTOS PRECÁRIOS NO ENTORNO DO RIO CAPIBARIBE}

Uma das questões principais que surgem quando se analisa o quadro socioespacial no entorno do Capibaribe é a condição da população de baixa renda que vive em assentamentos precários nas áreas ribeirinhas (Palafitas e favelas em áreas alagáveis). 0 PURA Capibaribe traz como princípio básico estabelecer uma relação de valorização e respeito com essa população ribeirinha, que realizam atividades cotidianas de subsistência e lazer às margens do rio, mas que também está submetida a condições muito duras de sobrevivência. $O$ aspecto mais importante que se destaca ao abordar essa população é a condição precária de moradia em que a maioria vive. Esta precariedade não se refere apenas a qualidade das moradias em si, mas sobretudo aos terrenos que ocupam em áreas sujeitas a alagamentos ou com instabilidade do solo. Esse quadro faz parte de um panorama mais amplo de problemas socioambientais, historicamente presente em muitas cidades brasileiras, onde a população de baixa renda busca responder às suas necessidades de moradia ocupando as áreas de risco ou fragilidade ambiental, que por isso mesmo são inadequadas para moradia e tem restrições legais para uso do solo.

As palafitas e mocambos se constituem em imagens emblemáticas da população ribeirinha, que persistem há séculos na paisagem do rio Capibaribe, apesar das inúmeras intervenções já realizadas para erradicá-las ao longo do processo de urbanização da cidade. Alguns projetos recentes no Capibaribe inclusive trazem como um dos seus eixos principais de ação a ideia de remoção das palafitas, como foi o caso do Projeto Recife sem Palafitas. Por outro lado, é importante observar como as palafitas e moradias ribeirinhas, ao mesmo tempo em que expressam as graves condições socioambientais dessa população, são também um símbolo da cultura local, e foram objeto de estudo para alguns dos intelectuais mais célebres de Pernambuco, como Josué de Castro e Gilberto Freyre.

Por se tratar então de uma questão antiga, que persiste na relação entre a cidade e o rio, o tratamento dos assentamentos precários às margens do Capibaribe é um grande desafio para o Parque Capibaribe, demandando abordagem criteriosa, que não deve reproduzir os equívocos de ações realizadas no passado, tais como: 1) o caráter higienista das ações que apenas removem a população pobre, sem requalificar as áreas públicas remanescentes e sem promover vitalidade urbana; e 2) Projetos habitacionais de reassentamento desconectados do tecido urbano, criando guetos às margens do rio.

Embora o foco principal do PURA Capibaribe não seja elaborar soluções habitacionais para a população ribeirinha, é evidente que o equacionamento desta demanda é essencial para viabilizar a implantação do Parque Capibaribe. Por esse motivo, foi realizado um mapeamento dos assentamentos ribeirinhos em condições mais críticas de habitabilidade e de ocupação das margens, que comprometem tanto a qualidade de vida desta população, como as condições ambientais do rio. Após o 
mapeamento, foi elaborado um dimensionamento preliminar da população e dos domicílios inseridos nestas áreas, considerando a necessidade de reestruturação urbanística das margens, com o provável reassentamento destas moradias. Buscou-se, enfim, apontar a dimensão e a distribuição espacial dos assentamentos considerados mais críticos em termos de condições de habitabilidade e comprometimento ambiental das áreas ribeirinhas, com o propósito de oferecer subsídios para o equacionamento desta demanda.

Ao observar a Figura 04 (Assentamentos precários no entorno do Capibaribe) pode-se verificar que grande parte deles está localizado ao longo da margem direita do rio. Isso ocorre tanto em relação ao número de assentamentos precários, como na quantidade de moradias e população residente nestas condições. Evidentemente também há assentamentos precários na margem esquerda, mas em quantidade e distribuição espacial bem menor do que na margem direita.

Figura 04: Assentamentos precários no entorno do Capibaribe9.

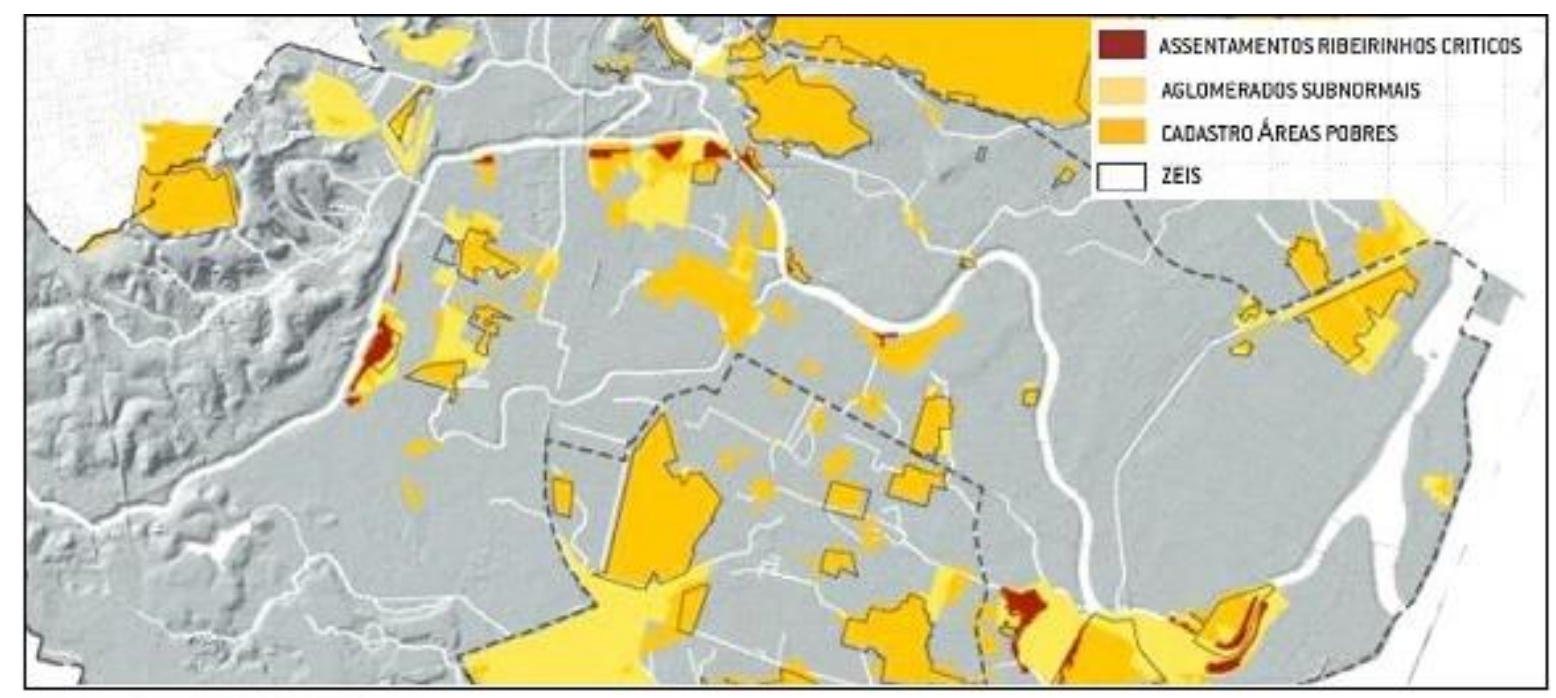

Fonte: INCITI, no prelo. (Elaborado em 2015)

As informações contidas da Tabela 01 a seguir confirmam a leitura acima, mas permite fazer também outras análises sobre este universo. Essa Tabela contém dados sobre alguns assentamentos ${ }^{10}$ precários no entorno do Capibaribe (dentro da cidade do Recife), mas com foco nos assentamentos em condições mais graves de habitabilidade localizados nas margens do rio, que se tornam prioritários para as ações relacionadas à proposta do Parque. Os critérios para avaliar esta demanda foram de dois tipos: 1) Assentamentos que ocupam áreas de riscos e alagáveis em condições muito precárias de habitabilidade; e 2) Assentamentos que impedem o acesso e uso público das margens do rio. A maior

\footnotetext{
${ }^{9}$ Estes dados são baseados nos seguintes levantamentos: Mapeamento e análise dos assentamentos precários no entorno do rio (realizado em 2012 pelo Observatório das Metrópoles Recife, segundo delimitações da legislação municipal (ZEIS), do IBGE 2010 (Aglomerados subnormais) e da pesquisa de Campo realizada em 2015 (em Assentamentos Ribeirinhos Críticos).

10 Vale ressaltar que a pesquisa sobre assentamentos precários aqui apresentada foi baseada nas seguintes fontes de informações: 1. Mapa com delimitação das ZEIS do Recife, no cadastro da PCR; 2. Mapeamento das áreas pobres da Recife Observatório das Metrópoles /UFPE; 3. Mapeamento e dados dos setores subnormais no Censo IBGE 2010 e 4 . Visitas de campo aos assentamentos em mês de 2016.
} 
parte dos assentamentos aqui mapeados apresentam estas duas condições, mas com diferentes graus de intensidade.

Tabela 01: Estimativa de População e Domicílios em Assentamentos Precários em 2015 a serem impactados pelo Parque Capibaribe.

\begin{tabular}{|c|c|c|c|c|}
\hline LOCAL / Bairro & Localidade & População & Habitação & $\begin{array}{l}\text { Subtotal p/ } \\
\text { bairro }\end{array}$ \\
\hline \multirow[t]{5}{*}{ Várzea } & Ribeirinhos Rua Divinolândia - Várzea & 109.4 & 26.1 & \\
\hline & Favela da Draga - Junto Escola João Pernambuco & 556.5 & 128.5 & \\
\hline & Malvinas/Vila Arraes & 968.8 & 248.8 & \multirow[t]{3}{*}{575.4} \\
\hline & Malvinas/Vila Arraes & 437.6 & 109.6 & \\
\hline & Vila Arraes & 865.9 & 217 & \\
\hline Caxangá & Engenho Poeta & 320 & 80 & 80 \\
\hline \multirow[t]{3}{*}{ Detran/Barbalho } & Skylab e Airton Senna & 548 & 134 & \\
\hline & Vila São João & 811 & 205 & \multirow[t]{2}{*}{462} \\
\hline & Ayrton Senna II & 1020 & 257 & \\
\hline Monteiro & Vila Esperança & 322.4 & 90.4 & 90.4 \\
\hline Poço da Panela & Poço da Panela & 87.3 & 20.4 & 20.4 \\
\hline Torre & Palafitas Santa Luzia & 1000 & 250 & \\
\hline \multirow[t]{4}{*}{ Afogados } & Palafitas pontilhão Metrô - Afogados/Coque & 108.4 & 25.3 & \\
\hline & Campo Tabaiares & 1181 & 296 & \multirow[t]{3}{*}{711.2} \\
\hline & Caranguejo/Campo Tabaiares & 1371 & 345 & \\
\hline & & 278.1 & 70.2 & \\
\hline \multirow[t]{3}{*}{ Coque } & Coque Palafitas braço morto do Capibaribe & 639 & 159.45 & \\
\hline & Coque/Vila Brasil & 206 & 53.5 & \multirow[t]{2}{*}{131.5} \\
\hline & Coque/Vila Brasil & 317.5 & 78 & \\
\hline \multirow[t]{2}{*}{ Vila Brasil } & Coque/Vila Brasil & 1000 & 247 & \\
\hline & Coque/Vila Brasil & 758 & 183 & 430 \\
\hline
\end{tabular}




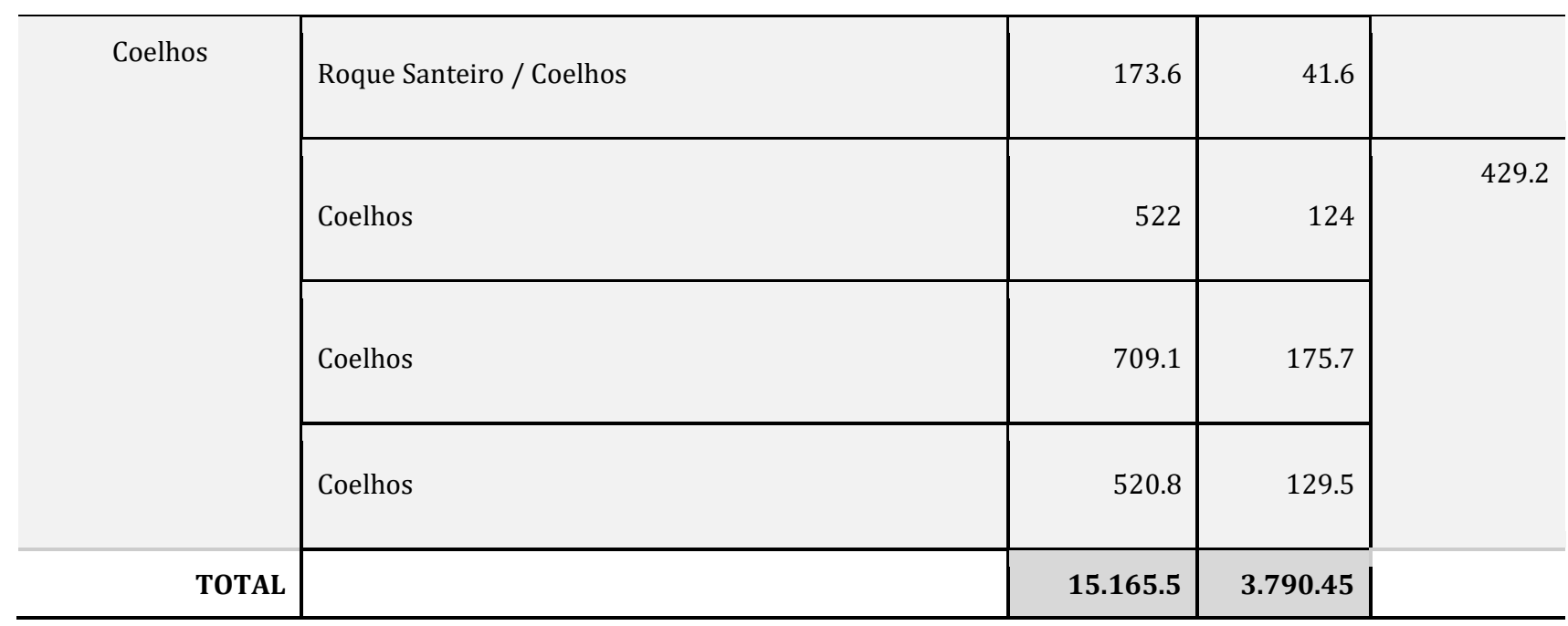

Fonte: INCITI, no prelo. (Elaborado em 2015)

As visitas de campo foram essenciais para complementar e atualizar as informações das fontes existentes. Ao longo de todo o percurso do rio no território do Recife buscou-se identificar os assentamentos em condições precárias de habitabilidade, mas também cuja ocupação comprometia o acesso público às margens do rio. Os assentamentos que apresentavam essa dupla condição foram então mapeados, buscando também identificar os setores censitários do IBGE (2010) onde estavam inseridos. Com base nas informações disponibilizadas pelo IBGE para cada setor censitário foi possível elaborar estimativas da população e do número de domicílios, da maior parte dos assentamentos, considerando percentuais dos setores que ocupavam.

A maior parte dos assentamentos deste levantamento está inserida em aglomerados subnormais, segundo a classificação do IBGE (2010), nesse caso, a delimitação dos setores censitários quase sempre coincide com os limites dos assentamentos precários. No entanto, nem toda a área dos assentamentos precários e setores censitários foram considerados prioritários para as intervenções urbanísticas relacionadas com o Parque Capibaribe. Baseados na observação de mapas e de visitas em campo foram apontados percentuais de cada setor que deveriam ser considerados objeto de intervenção urbanísticas de grande porte, com reassentamento habitacional de uma parte relevante da população. Alguns assentamentos inclusive foram considerados em 100\% de sua área e população. Segundo estes critérios foi elaborada a estimativa da população e do número de domicílios dos assentamentos precários (demonstrada na Tabela 01) que devem ser impactados com intervenções urbanísticas para viabilizar a implantação do Parque Capibaribe.

Evidentemente, os números obtidos por esta metodologia representam apenas uma estimativa preliminar do público para estas intervenções, mas que indicam uma ordem de grandeza deste universo, importante para avaliar e dimensionar as intervenções urbanísticas necessárias. Além das limitações operacionais deste trabalho de pesquisa, os procedimentos de pesquisa aqui utilizados, sem visitas de cadastro domiciliar, se justificam para evitar a grande expectativa gerada sobre a população, 
quando se realiza levantamento domiciliar em assentamentos populares. A experiência mostra que essa expectativa resulta inclusive na intensificação das ocupações irregulares destas localidades, e no agravamento das condições de habitabilidade, diante da expectativa da população em receber benefícios do projeto de intervenção em curso.

Apesar do número relevante de domicílios e população ribeirinha a ser impactada pelas intervenções urbanísticas do Parque Capibaribe, deve-se destacar que este número se refere a quase toda a margem do Capibaribe no território do Recife, envolvendo cerca de $30 \mathrm{~km}$ (nas duas margens). Neste sentido, trata-se de uma meta acessível para um projeto urbanístico e habitacional deste alcance, que além de beneficiar a população dos assentamentos precários, visa beneficiar toda a população do Recife que passará a dispor de espaços públicos de convivência em diversos bairros ao longo do Capibaribe, ampliando as possibilidades de integração socioespacial desta cidade.

\section{MAPEAMENTO DA SÍNTESE DE VULNERABILIDADE SOCIAL (IDV11) DO RECIFE}

Neste tópico foi desenvolvida uma análise do território do Recife com base nos indicadores de vulnerabilidade social, elaborados para a busca ativa do Plano Brasil sem Miséria ${ }^{12}$. De acordo com a definição da Secretaria de Avaliação e Gestão da Informação (SAGI) do Ministério de Desenvolvimento Social e Combate à Fome (MDS), o aplicativo de Identificação de Localidades e Famílias em Situação de Vulnerabilidade (IDV13) foi desenvolvido para construção de mapas de pobreza ao nível de estados, municípios e setores censitários, apresentando dados e indicadores de pobreza, vulnerabilidade e grupos populacionais específicos. Com isso é possível dimensionar e localizar as áreas com maior concentração de famílias em situação de pobreza e/ou vulnerabilidade.

Dentre os indicadores relacionados no IDV está o de Vulnerabilidade Social para Busca Ativa do Plano Brasil sem Miséria, que integra o conjunto de estratégias do plano para localização de pessoas em situação de vulnerabilidade e inclusão em redes de proteção social. As variáveis que compõe este indicador têm origem no Censo Demográfico 2010 e são as seguintes: (1) Situação do Domicílio; (2) Domicílios particulares permanentes; (3) População residente em domicílios particulares permanentes; (4) População residente em domicílios particulares permanentes, com rendimento nominal mensal per capita de até 70 reais; (5) Domicílios particulares permanentes em outra condição de ocupação (não são próprios, alugados, nem cedidos; (6) Domicílios particulares permanentes com outra forma de abastecimento de água; (7) Domicílios particulares permanentes sem banheiro de uso exclusivo dos moradores e nem sanitário; (8) Domicílios particulares

\footnotetext{
11 Os dados e indicadores apresentados no IDV foram obtidos do Censo Demográfico 2010 e do Cadastro Único de Programas Sociais de agosto de 2011.

12 O Plano Brasil sem Miséria foi lançado em 02/06/2011 pelo decreto no 7.492 com o objetivo de superar a extrema pobreza no país até o final de 2014. As informações deste plano estão em http://www.brasilsemmiseria.gov.br.

${ }^{13}$ Em http://aplicacoes.mds.gov.br/sagirmps/idv/ acessado em 22/09/2014
} 
permanentes sem energia elétrica; (9) Pessoas responsáveis analfabetas; (10) Crianças de 0 a 6 anos; e (11) Pessoas com 65 anos de idade ou mais.

As variáveis deste indicador apresentam dados relativos aos domicílios ${ }^{14}$, tais como a condição de ocupação, forma de abastecimento de água, tipo de esgotamento sanitário e fornecimento de energia elétrica; e da população quanto à renda per capita, grau de escolaridade dos responsáveis e faixa etária de seus moradores. De modo preliminar, pode-se inferir que de acordo com os objetivos do plano ao qual este conjunto de variáveis se inserem, a sobreposição destas camadas de informação orienta a observação de situações extremadas de condições de vida em cada território, permitindo identificar não apenas os resultados por setor censitário, mas também a percepção de agrupamento e segregação espacial dos conjuntos analisados.

Foi tomado então como base de análise o conjunto de tabelas e mapas disponibilizados ${ }^{15}$ sobre o indicador de Vulnerabilidade Social da Busca Ativa do Plano Brasil sem Miséria, para o município do Recife, além das bases cartográficas e dados complementares do Censo Demográfico 2010. 0 objetivo foi constituir uma síntese do indicador, expressa em graus de vulnerabilidade social da população do Recife por setor censitário, que é o menor recorte territorial possível com esta base de dados.

Os graus de vulnerabilidade social foram elaborados a partir dos cortes de legenda já constantes nos mapas temáticos disponibilizados. Estes cortes inferem sobre uma escala de vulnerabilidade por tema, que vai desde os valores mais baixos de pessoas ou domicílios por setor censitário (baixa vulnerabilidade ou inexistente) até valores mais altos (alta vulnerabilidade). Assim, quanto maior a quantidade de pessoas ou domicílios por setor em condições de vulnerabilidade relacionadas aos temas, maior é o grau de vulnerabilidade do setor. Partindo da numeração das variáveis do indicador anterior, os temas relacionados nesta síntese foram: (1) População residente em domicílios particulares permanentes, com rendimento nominal mensal per capita de até 70 reais; (2) Domicílios particulares permanentes em outra condição de ocupação (não são próprios, alugados, nem cedidos); (3) Domicílios particulares permanentes com outra forma de abastecimento de água; (4) Domicílios particulares permanentes sem banheiro de uso exclusivo dos moradores e nem sanitário; (5) Domicílios particulares permanentes sem energia elétrica; (6) Pessoas responsáveis analfabetas; (7) Crianças de 0 a 6 anos; (8) Pessoas com 65 anos de idade ou mais.

Para cada variável temática foi atribuído como fator de ponderação um valor mínimo e máximo (0 - vulnerabilidade inexistente e 3 - vulnerabilidade alta) à escala das legendas, independente da gama de cortes existentes, de modo a qualificar como equivalente a relação de importância das variáveis entre si. Assim, cada setor censitário foi valorado de acordo com os resultados apresentados

\footnotetext{
14 Os domicílios referidos são os particulares permanentes, que é a variável adotada pelo indicador e, de acordo com o Censo Demográfico 2010, totalizam 470.754 frente a um universo de 477.166 domicílios no município do Recife.

15 Tabelas e mapas em http://aplicacoes.mds.gov.br/sagirmps/idv/tabela_basico6_fam.php?ibge=261160 e http://aplicacoes.mds.gov.br/sagirmps/idv/inikml.php?ibge=261160\&uf=PE\&nome=Recife acessados em 22/09/2014.
} 
por tema conforme seu enquadramento nos cortes das respectivas legendas, e associado a uma escala crescente de vulnerabilidade, equivalente nos valores mínimos e máximos para o conjunto dos temas.

A partir da valoração do grau de vulnerabilidade por setor censitário em cada tema, foi realizada a soma das oito camadas de informação para obtenção da síntese. Com a sobreposição das informações contidas nas camadas, foi possível identificar o posicionamento de cada setor censitário na escala elaborada, evidenciando o grau de vulnerabilidade social das populações no conjunto dos oito temas que compõe o indicador. Os resultados finais estão representados no mapa Síntese da Vulnerabilidade Social para Busca Ativa do Plano Brasil sem Miséria (IDV) no município do Recife, e de acordo com a legenda, totalizam as seguintes quantidades de pessoas e domicílios ${ }^{16}$ por grau de vulnerabilidade:

Tabela 02: Grau de Vulnerabilidade

\begin{tabular}{l|r|r|r|c}
\hline \multirow{2}{*}{ Graus de vulnerabilidade } & \multicolumn{2}{c|}{ Pessoas } & \multicolumn{2}{c}{ Domicílios } \\
\cline { 2 - 5 } & \multicolumn{1}{c|}{ Qtd. } & \multicolumn{1}{c}{$\%$} & \multicolumn{1}{c}{ Qtd. } & \multicolumn{1}{c}{$\%$} \\
\hline N/A $^{17}$ ou vulnerabilidade inexistente & 9 & $0,0 \%$ & 5 & $0,0 \%$ \\
\hline baixa vulnerabilidade & 21.686 & $1,4 \%$ & 7.558 & $1,6 \%$ \\
\hline média-baixa vulnerabilidade & 435.452 & $28,5 \%$ & 141.516 & $30,1 \%$ \\
\hline média vulnerabilidade & 705.109 & $46,1 \%$ & 212.746 & $45,2 \%$ \\
\hline média-alta vulnerabilidade & 343.501 & $22,4 \%$ & 101.660 & $21,6 \%$ \\
\hline alta vulnerabilidade & 24.515 & $1,6 \%$ & 7.269 & $1,5 \%$ \\
\hline Total & $\mathbf{1 . 5 3 0 . 2 7 2}$ & $\mathbf{1 0 0 , 0} \%$ & $\mathbf{4 7 0 . 7 5 4}$ & $\mathbf{1 0 0 , 0} \%$ \\
\hline
\end{tabular}

Fonte: INCITI, no prelo. (Elaborado em 2015)

Para observar melhor as relações espaciais que resultam dos graus de vulnerabilidade dos setores censitários, foi elaborada uma análise de autocorrelação espacial ${ }^{18}$ que permitiu identificar o nível de probabilidade do padrão de agrupamento dos resultados ser randômico (ao acaso), e a visualização global do agrupamento e dispersão dos setores censitários analisados a partir de seus valores e relações de vizinhança. O mapa Síntese da Vulnerabilidade Social para Busca Ativa do Plano Brasil sem Miséria (IDV) no município do Recife - Autocorrelação Espacial dos Setores Censitários

\footnotetext{
16 Valores extraídos a partir da variável (2) Domicílios particulares permanentes e seus residentes que no município do Recife totalizam respectivamente 470.754 e 1.530 .272$.

17 Não se aplica onde não há domicílios particulares permanentes, notadamente em setores do Censo Demográfico 2000 que foram excluídos no Censo 2010 e, por exemplo, no setor em que se localiza o Aeroporto Internacional do Recife.

18 A ferramenta estatística espacial chama-se Autocorrelação Espacial Moran's I e, como forma de conceituar as relações espaciais entre os setores censitários valorados, foi definido que o impacto de um valor de setor o sobre o outro diminui com o aumento da distância entre eles (Inverso da Distância). Informações mais detalhadas em http://webhelp.esri.com/arcgisdesktop/9.2/index.cfm?TopicName=Spatial_Autocorrelation_(Morans_I)_(Spatial_Statistics).
} 
apresenta os resultados desta análise. Em função dos graus de vulnerabilidade dos setores censitários e suas relações de vizinhança, foi estabelecida uma classificação destes mesmos setores em dispersos, heterogêneos e agrupados. Dessa forma, é possível identificar de modo mais claro as situações de agregação e segregação territorial destes grupos sociais formados a partir do grau de vulnerabilidade social elaborado na síntese.

Figura 05: Mapa de vulnerabilidade social (quanto mais escuro, mais vulnerável)

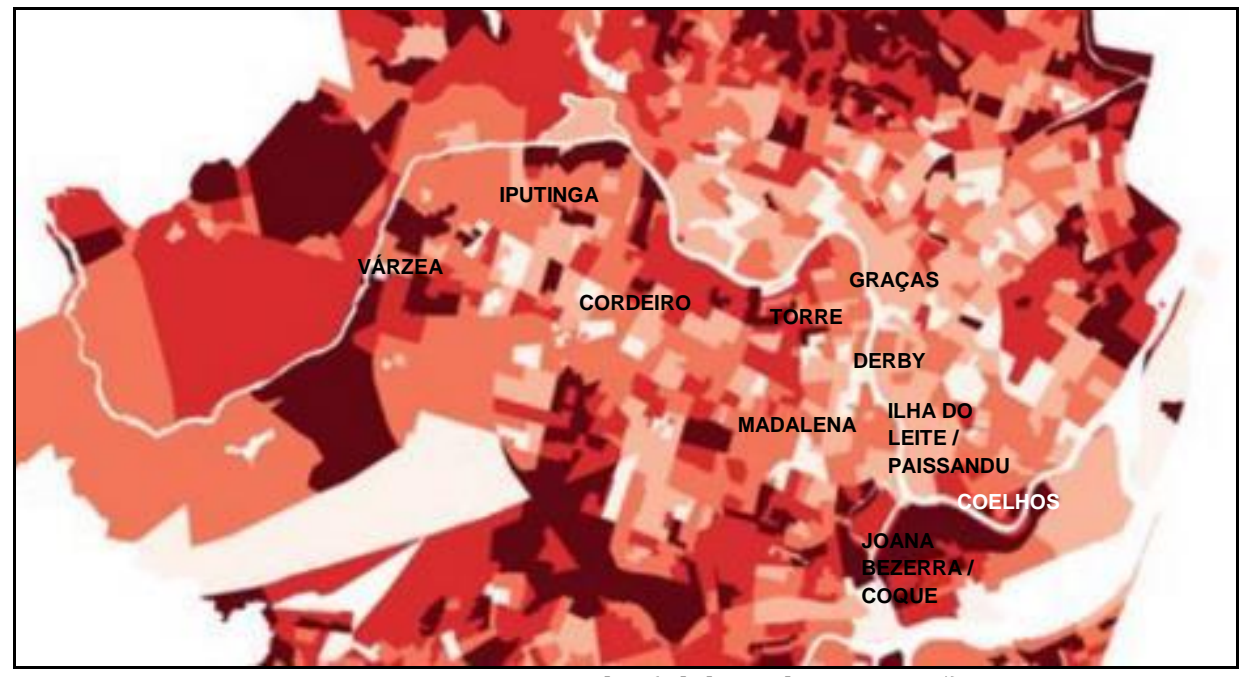

Fonte: INCITI, no prelo. (Elaborado em 2015)

Ao analisar a Figura 05 podemos confirmar que a distribuição das populações com maior nível de vulnerabilidade social no entorno do Capibaribe ocorre de forma muito mais acentuada ao longo da sua margem direita. Essa leitura também coincide com a leitura do mapa de assentamentos precários no entorno do rio Capibaribe, apresentados na Figura 04. Buscando setorizar alguns trechos da orla urbana do Capibaribe em relação a vulnerabilidade social podemos apontar três setores mais críticos com base neste mapa: o Bairro da Várzea; a região formada pelos bairros da Iputinga, Cordeiro e parte da Torre; e o setor que envolve a Ilha Joana Bezerra / Coque e a Orla dos Coelhos. Ao analisar a relação entre conexões urbanísticas e vulnerabilidade social, percebemos que o trecho onde existe maior desequilíbrio socioeconômico entre as margens é justamente o trecho onde não há conexões de travessia, destacando-se o trecho já citado que vai desde a rodovia BR-101 até a ponte do Vintém Parnamirim, que possuem apenas duas travessias de pedestres: 01 no Parque de Santana e outra entre o bairro do Monteiro à estrada do Barbalho na Iputinga (demonstrado na Figura 03).

Por outro lado, (ainda observando a Figura 05 - Mapa de Vulnerabilidade) no trecho que envolve os bairros da Madalena, Graças, Derby, Ilha do Leite e Paissandu, pode-se identificar que os níveis de vulnerabilidade social são baixos e equilibrados nas duas margens. Conforme já apontado e demonstrado na Figura 03 (Mapa Análise Sintática de Integração / desintegração entre bairros) esse é 
um dos trechos com maior nível de integração espacial, havendo um número relevante de travessias sobre o rio, e onde diversas vias estão inseridas no núcleo de integração da cidade.

\section{COMPARANDO VULNERABILIDADE SOCIAL E SINTAXE ESPACIAL}

Neste tópico buscou-se confrontar o mapeamento da vulnerabilidade social, com as análises de sintaxe espacial. A principal base para a análise deste tópico são os mapas que sintetizam estas duas abordagens (Sintaxe espacial e vulnerabilidade), apresentados nas Figuras 03 e 05. Ao cruzar as informações do mapa síntese de vulnerabilidade (IDV) com os valores de Integração Global do sistema, é possível notar que boa parte das áreas mais conectadas e acessíveis possuem regiões em que o índice de vulnerabilidade (IDV) é maior, representando áreas com piores condições socioeconômicas e de infraestrutura. Nas áreas ribeirinhas essa relação é mais perceptível em bairros como Torre, Graças, Derby e Madalena, que possuem linhas com conexões fortes e integradas ao tecido urbano, nas duas margens do rio. São áreas onde há conexões das margens com a cidade, mas também boas conexões de travessia do Capibaribe.

Essa relação entre integração espacial e vulnerabilidade social não é uniforme ao longo de todo o percurso do Capibaribe no Recife. Nos bairros do Cordeiro e Iputinga, de um lado, e Poço da Panela e Santana na margem oposta, acontece uma relação inversa, pois a margem direita apresenta linhas com maior integração espacial e índices maiores de vulnerabilidade, enquanto a margem esquerda tem a condição contrária. Alguns aspectos parecem explicar essa situação. Um dos mais relevantes é a ausência de travessias efetivas neste trecho, isolando (em parte) o fluxo da população de maior renda que poderia circular pelas áreas de baixa renda, gerando oportunidades para atividades econômicas nessa região. É de longa data o projeto da terceira perimetral do Recife que faria a conexão entre as duas margens nesse trecho, mas que tem sido sistematicamente adiada. É relevante considerar também que uma das linhas de maior integração da margem direita, avenida Maurício de Nassau, foi implantada há pouco mais de uma década, mas a estrutura fundiária nesta região ainda não sofreu grandes mudanças.

Com as pesquisas de campo e as análises desenvolvidas, destaca-se que grande parte das intervenções urbanísticas realizadas nas áreas ribeirinhas no último século reforçaram o papel do Capibaribe como barreira socioespacial. Durante longo tempo prevaleceu a visão política que promoveu a remoção de assentamentos precários da margem esquerda (nos bairros de alta renda como Casa Forte, Parnamirim e Santana) para reassentar sistematicamente essa população em conjuntos habitacionais na margem direita (em bairros mais populares como Cordeiro, Iputinga, comunidade de Santa Luzia). Este padrão de intervenções apenas reforçou o contraste socioeconômico entre as duas margens e, consequentemente o nível de segregação socioespacial da cidade, já que o 
Capibaribe ainda se mantém como barreira difícil de transpor em boa parte do território urbano. 0 resultado destas ações pode ser constatado na Figura 06 a seguir demonstrando a concentração de média e alta renda na margem esquerda do rio.

Figura 06: Renda Per Capita em 2015 ao longo do rio Capibaribe no Recife

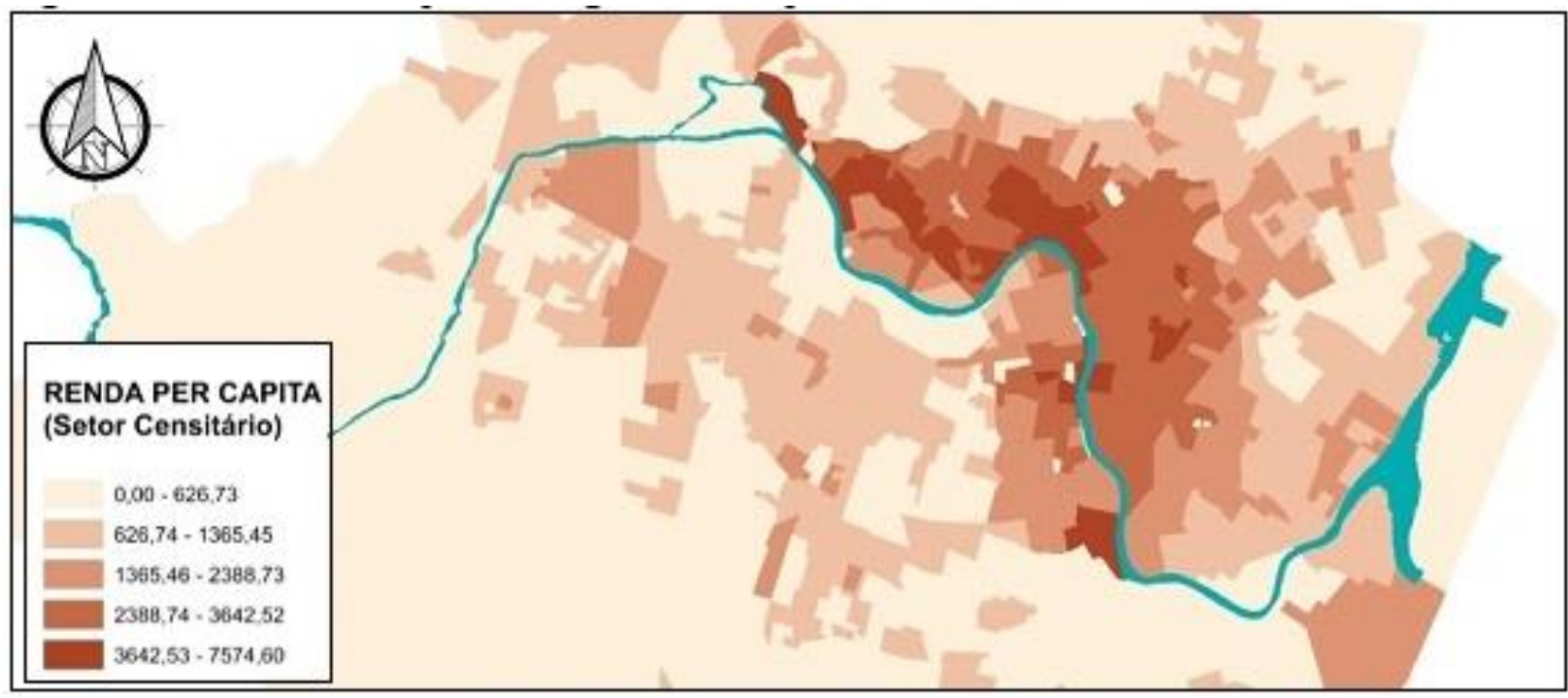

Fonte: INCITI, no prelo. (Elaborado em 2015)

Assim, conforme já foi observado, o rio Capibaribe atua nesta área como uma barreira entre as porções norte e sul, segregando os bairros de alta renda (Casa Forte, Monteiro e Poço da Panela) dos bairros de menor renda (Cordeiro e Iputinga). A perspectiva do Parque Capibaribe diante desse quadro é diminuir o papel de barreira do rio e promover uma maior integração entre as margens neste trecho, mas sem trazer os impactos negativos de uma conexão rodoviária nas áreas mais amenas, situada nos bairros do Poço da Panela e Santana. A conexão neste trecho é essencial inclusive para estabelecer novas rotas de ciclistas e pedestres que podem trazer vitalidade para a orla. 


\section{PARQUE CAPIBARIBE COMO INTEGRADOR SOCIOESPACIAL}

No caso do Recife, um indicador relevante da relação entre a estrutura urbana e o rio Capibaribe é a baixa qualidade, ou mesmo a escassez dos espaços públicos nas áreas ribeirinhas. Nas pesquisas de campo realizadas em toda a orla urbana do Capibaribe, foi possível observar que a maioria das terras junto às margens estão em uma destas condições: fundos de lotes privados (que não utilizam as áreas junto ao rio); terras de propriedade governamental sem uso público (terra pública sem uso público); ou áreas ocupadas por assentamentos precários (palafitas, favelas), onde os espaços das margens também não estão "abertos para a cidade”.

Assim, as análises das diversas áreas ao longo do rio buscaram enxergar potenciais e restrições para uma maior valorização dos espaços, relacionando os dados sintáticos, principalmente integração, com os condicionantes históricos da formação do lugar. Uma das referências usada aqui para avaliar a qualidade dos espaços urbanos ao longo do rio Capibaribe foi o estudo desenvolvido por Mello (2012) que foca sobre a relação entre algumas cidades brasileiras e os corpos d'água. Neste estudo a autora aponta duas vertentes principais: a valorização e integração dos corpos d'água com a paisagem urbana; e outra de negação. Recife, no presente cenário, se enquadra majoritariamente na segunda vertente onde "corpos d'água são desconsiderados, edificações e os lotes lindeiros ficam de costa para eles" (MELLO, 2012, p. 67). Apresentamos a seguir a análise das intervenções propostas pelo Parque Capibaribe, na perspectiva da sintaxe espacial, buscando verificar o potencial destas intervenções em relação a integração socioespacial da cidade.

\section{A relação da Cidade com o Rio Capibaribe vista através da Sintaxe Espacial}

Nas pesquisas de campo realizada no bairro das Graças para avaliar a relação entre o tecido urbano e o rio onde foi implantado o projeto Piloto do Parque Capibaribe, o Jardim Baobá, trazem um resultado bastante expressivo. Constatou-se que a maioria dos lotes que facejam as margens do rio estão fechados sem nenhum acesso ao rio, e muitos usam seus "fundos" como estacionamento. Outros trechos são compostos por vias expressas, que impedem o acesso às margens, e em alguns pontos a mata nativa faz esse papel. Sem dúvida temos um grande potencial de paisagem desperdiçado, por não haver uma configuração urbana que permita chegar e percorrer na área ribeirinha. Enfim, apesar da cidade ter dado as costas ao rio, os resultados das pesquisas de campo apontam também para uma variação na configuração espacial ao longo do rio, que revela potencial diverso para fomentar vitalidade urbana nos espaços abertos ao longo das suas margens.

Na perspectiva de aumentar os espaços públicos em muitos dos bairros da cidade, o PURA Capibaribe busca disponibilizar as áreas das margens urbanas do rio, que atualmente estão 
inacessíveis ou extremamente segregadas, para serem apropriadas como parques ou praças públicas. Entretanto, para que esse processo de apropriação seja bem sucedido, fez-se necessário também elaborar intervenções urbanísticas para articular estes "novos" espaços ao conjunto urbano, ou seja, "abrir" o rio para cidade. Neste sentido, uma das estratégias centrais para isso é melhorar o nível de integração da malha urbana nas áreas ribeirinhas. Na verdade, em muitos trechos trata-se mesmo de complementar a malha urbana que parece inacabada, observando a grande quantidade de lotes fechados para o rio, terras públicas sem destinação adequada, ou assentamentos precários com espaços urbanos extremamente segregados.

Dentro da lógica de complementar o tecido urbano e melhorar seu nível de integração, está incluído também a implementação de novas travessias em pontos estratégicos, especialmente trechos de maior segregação espacial, que coincidem muito com os trechos de maiores contrastes socioeconômicos entre as duas margens. É fundamental ressaltar ainda que, dentro da concepção do projeto do Parque Capibaribe, a complementação do tecido urbano está focada principalmente na criação ou adaptação de vias com prioridade para pedestres e bicicletas. Trata-se de devolver as margens do Capibaribe para as pessoas, e não para os automóveis. Esta observação é importante porque implantar vias expressas nas margens do rio também aumentaria o nível de integração sintática do tecido urbano, mas sem trazer as qualidades desejadas para esse contexto.

As intervenções propostas para o Parque Capibaribe possuem dois horizontes de tempo, a primeira etapa tem como prazo o ano de 2020, enquanto a segunda almeja uma transformação da cidade até o ano de 2037, data emblemática para o Recife que completará 500 anos de sua fundação. A concepção do Parque Capibaribe buscou explorar as qualidades paisagística e naturais das margens do rio, assim como seu grande potencial de articulação sobre o tecido urbano. A aplicação das categorias projetuais (chegar, atravessar, percorrer, abraçar e ativar), ocorrerá de forma mais incisiva na área delimitada no seu entorno que foi denominada de Zona Parque. Esta Zona tem o propósito de ampliar a área de influência deste plano, permitindo o transbordamento das intervenções relativas ao Parque no espaço urbano. Partindo da base conceitual construída na elaboração do PURA Capibaribe, foram estabelecidas diretrizes norteadoras para as diversas intervenções ao longo do rio, onde se busca oferecer espaços urbanos de qualidade, para serem implantadas por diversos atores em cada local do Parque (gestão dos espaços públicos). 
Figura 07: Proposta de conexões entre áreas verdes e equipamentos urbanos e culturais inseridos na Zona Parque

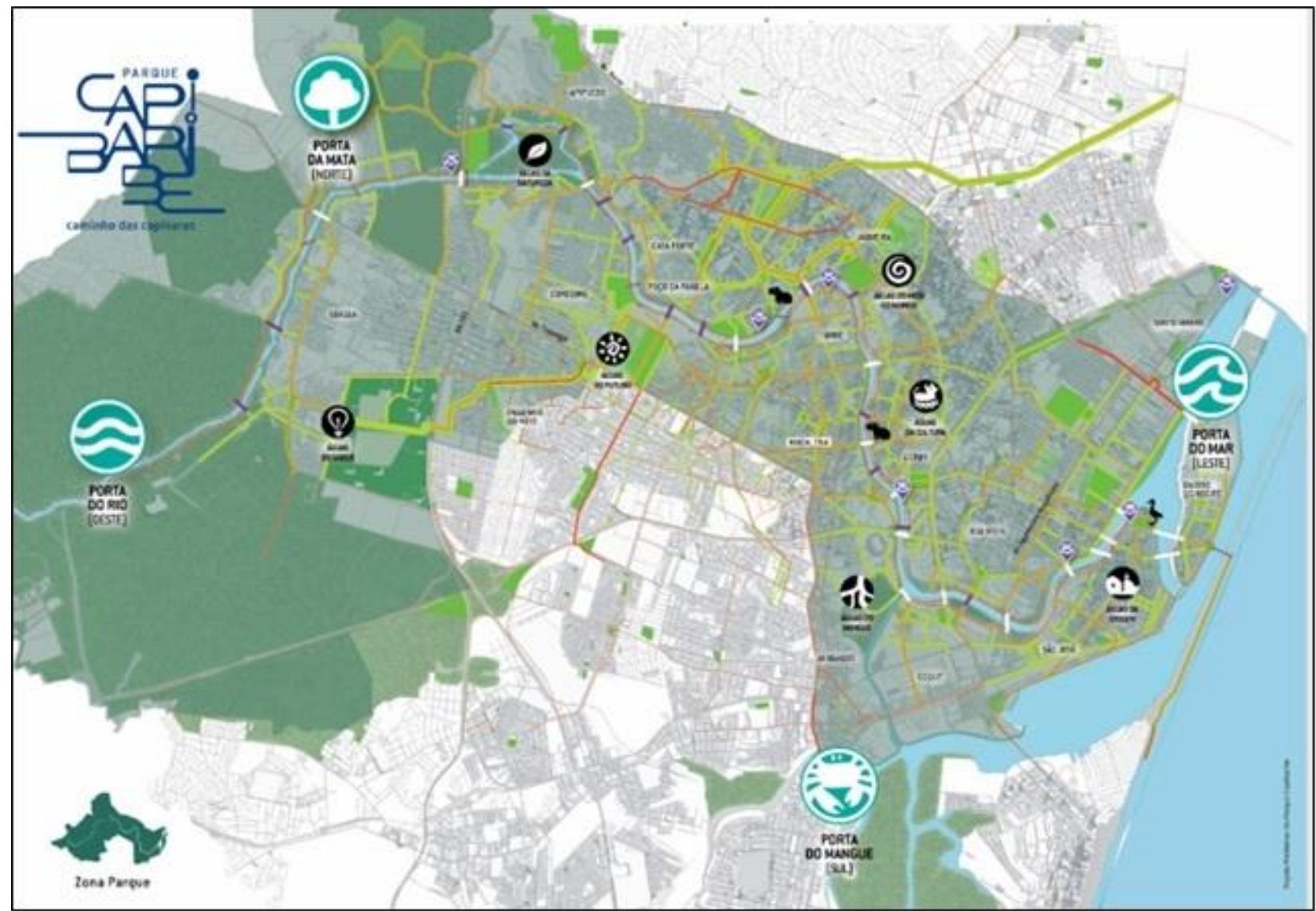

Fonte: INCITI, no prelo. (Elaborado em 2014)

Ao longo da implantação de todo o Parque pretende-se implantar cerca de $45 \mathrm{Km}$ de vias cicláveis, conectando a cidade de leste a oeste, e passando por mais de 30 bairros. Essa conexão também inclui a implantação de calçadas amplas e arborizadas para os pedestres, um elemento simples de urbanização, mas ainda com uso limitado no contexto do Recife. Serão implantados também 12 novas travessias (pontes) para pedestres (e ciclistas); assim como mais de 90 "infiltrações", ou seja, vias com atributos que o aproximam e atraem para o Parque (passeios, alamedas arborizadas, ciclovias). Complementam esse conjunto diversos espaços de lazer e contemplação para "abraçar" o rio (parques, decks, praças). Com essa complementação do tecido urbano, poderá haver um considerável acréscimo de permeabilidade das margens. 
Figura 08: Proposta de Integração e Travessias entre as ruas na margem do rio.

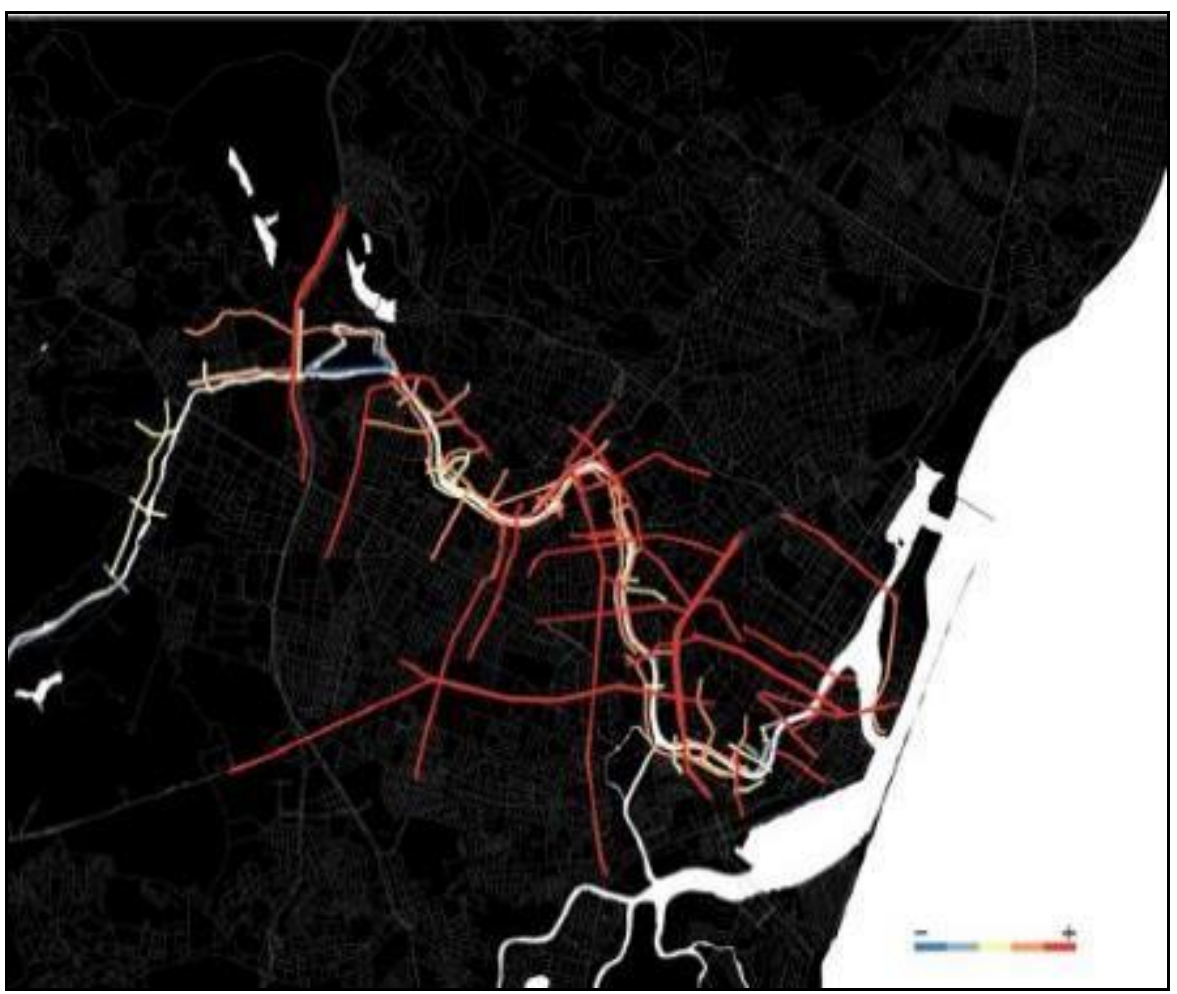

Fonte: INCITI, no prelo. (Elaborado em 2015)

Ao comparar as Figuras 03 (Mapa Análise Sintática de Integração / desintegração entre bairros) e 08 (Proposta de Integração e Travessias entre as ruas na margem do rio) pode-se perceber as duas situações (atual e da intervenção proposta), com ganhos expressivos que podem ser alcançados em termos de integração da malha urbana junto ao rio. Além disso, as travessias propostas também melhoram o resultado da interação entre as duas margens, que ficarão mais conectadas principalmente nas regiões entre a BR - 101 até o bairro do Parnamirim/Torre. As diferenças de níveis de renda separadas pelo rio, podem ser diminuídas a partir dessa integração entre as margens com as travessias propostas que priorizam os pedestres e ciclistas, possibilitando que a população, independentemente de sua renda, tenha o direito de transitar livremente entre ambos os lados, e como o modal estimulado é o da mobilidade ativa (pedestre e ciclista) tal prática poderá promover a interação e a aproximação entre os bairros de classe alta, média e baixa.

Destaca-se também, que com a implantação dos diversos espaços de lazer e contemplação para "abraçar" o rio (parques, decks, praças) a possibilidade de diminuição de vulnerabilidade social da população ribeirinha, por meio da promoção do protagonismo das comunidades de baixa renda num processo de ativismo em busca de espaços colaborativos e sustentáveis. Podemos citar como prática/ exemplo de um processo de desenvolvimento social em fase de implementação, desde 2015, o caso da 
ocupação da Vila Santa Luzia ${ }^{19}$, comunidade de baixa renda, na margem direita do rio, no bairro da Torre. 0 despertar para o enfrentamento das questões sociais, levou a equipe do INCITI, sobre o entendimento de convocar outros grupos, coletivos e ações, com propósitos parecidos, para desenvolver a metodologia do urbanismo emergente ${ }^{20}$ com os moradores locais.

Figura 09: Horta comunitária e espaço recreativo com biblioteca nas margens do rio Capibaribe - Vila Santa Luzia.
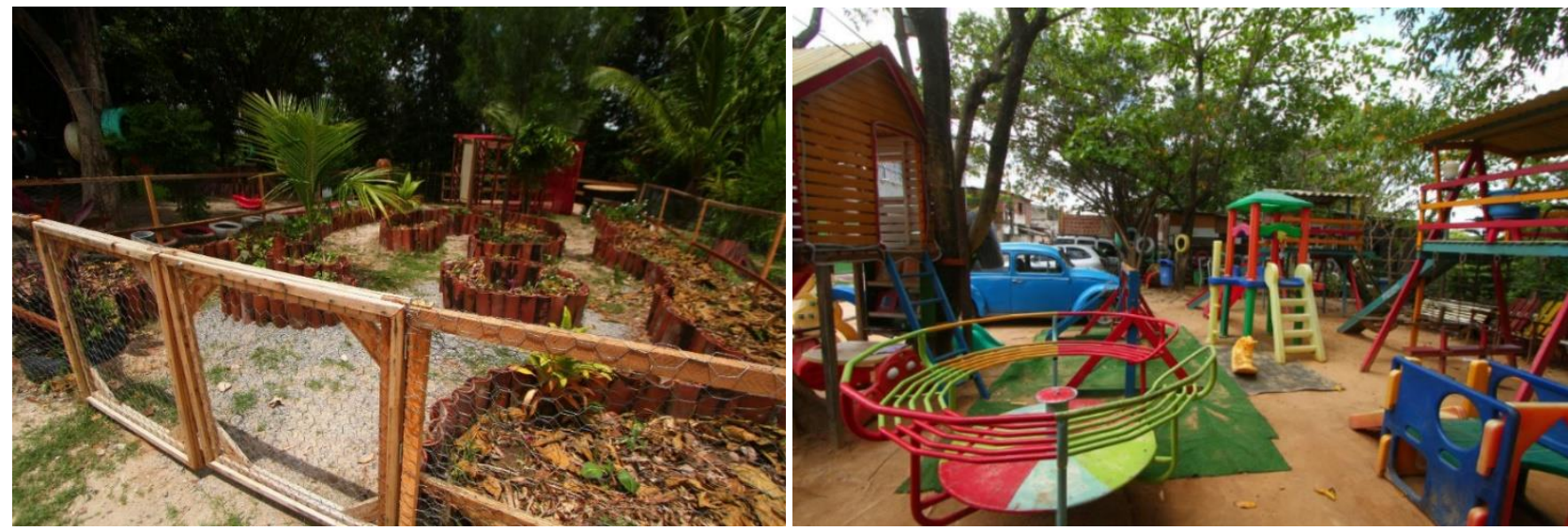

Fonte: JConline (2018).

Tal metodologia se iniciou com a descoberta da área por meio dos seus moradores locais / ribeirinhos, que apresentaram à equipe os espaços livres públicos com potencial de convívio social e que estavam subutilizados por causa da falta de reconhecimento. Reconhecidas as relações de afetividades dos moradores com o lugar se iniciaram uma série de atividades com ações simples de limpeza e criação de mobiliários para as crianças. Este trabalho desencadeou um processo de auto estima e confiança na comunidade e de entendimento de seu papel como protagonista e cidadão que necessita se organizar como grupo para discutir seus direito e deveres em sua comunidade.

\section{CONCLUSÃO}

A configuração urbanística resultante dos processos urbanísticos estudados reforça a segregação socioespacial e o baixo nível de integração do tecido urbano junto as margens do Capibaribe. As evidências desse quadro foram observadas tanto nos mapas de renda, de análise sintática, bem como, de vulnerabilidade social, onde verificamos aspectos relevantes que merecem destaque: os trechos de maior contraste socioeconômico entre as duas margens são também os que apresentam menos conexões de travessia do rio, com destaque para o trecho Iputinga e Cordeiro $\mathrm{x}$

\footnotetext{
${ }^{19}$ Neste trecho da cidade, ao identificar que além da necessidade das intervenções urbanísticas, também seria necessário um projeto de desenvolvimento social, a comunidade continua sendo assistida com assessoria técnica de alguns coletivos como o INCITI e o MASSAPÊ com a criação de uma horta comunitária.

200 urbanismo emergente se baseia nos "processos de organização social e urbana que surgem sem mediação ou 'provocação'” (FREIRE, 2009). Envolve a participação espontânea e a conquistada.
} 
Poço da Panela e Santana. A maior parte do tecido urbano nas regiões ribeirinhas do Capibaribe apresenta baixos níveis de integração espacial, onde pode-se destacar apenas dois trechos mais integrados (Avenida Beira Rio na Madalena e Rua da Aurora com Rua do Sol).

Os trechos cujos tecido urbano apresentam menores níveis de integração espacial coincidem (em grande parte) com as áreas com menor número de travessias sobre o rio, onde se destacam os bairros do Poço da Panela e Santana. Considerando o panorama acima, pode-se entender melhor a expressão muito propagada de que "a cidade do Recife virou as costas para o Capibaribe", pois atualmente o tecido urbano no entorno deste rio não contribui para a conexão das suas margens ao conjunto do espaço urbano.

Em síntese, boa parte do desafio a ser enfrentado para urbanização do Parque Capibaribe é complementar o tecido urbano da cidade, para que ele alcance as margens do rio de forma mais qualificada, reduzindo a fragmentação existente. Por outro lado, essa complementação do tecido não significa remover assentamentos precários para implantar vias expressas de veículos, pois isso resultaria apenas no isolamento das áreas ribeirinhas. Trata-se de reconquistar as margens do rio para implantar espaços públicos que favoreçam a integração social.

A perspectiva trazida então pelo Parque Capibaribe é estabelecer progressivamente algumas conexões estratégicas das zonas ribeirinhas entre si e com o tecido urbano de toda a cidade. Estas conexões devem servir tanto para estabelecer novos pontos de travessia, como para ligar trechos da mesma margem com o tecido urbano do entorno, especialmente com as áreas de maior vitalidade urbana. De forma geral, o propósito é "complementar" o tecido urbano que atualmente é interrompido ou fragmentado à medida que se aproxima das áreas ribeirinhas do Capibaribe. Portanto, ressalta-se que a rede formada por este rio e seus afluentes tem um grande potencial para (re) assumir seu papel como elemento de articulação e integração socioespacial do território urbano do Recife. Assim, a proposta elaborada para o Parque Capibaribe tem o objetivo não somente de oferecer uma nova relação entre o rio e o conjunto urbano, mas também aproveitar essa oportunidade para refazer boa parte da malha urbana desta cidade, tendo o rio como principal elemento de articulação.

O parque Capibaribe já está sendo implantado por módulos na cidade, o primeiro foi implantado em março de 2016, reconhecido como o Jardim Baobá, este espaço que antes era utilizado como estacionamento de carros, foi transformado em um agradável espaço de contato com a natureza entre pessoas de diversas localidades da Região Metropolitana do Recife. Atualmente está em fase de implementação a Via Parque das Graças, depois de um longo processo participativo motivado pela Associação Por Amor às Graças, no bairro das Graças, que possibilitou uma construção colaborativa de espaços socialmente inclusivos. Num processo de mudança de paradigma, o que antes seria destinado a construção de vias marginais exclusivas para carros, passa a ser concebido como um parque linear humanizado que valoriza o rio e toda a população residente do bairro. 
Portanto, as ações aqui citadas, da Vila de Santa Luzia, do Jardim Baobá e da Via Parque das Graças, ilustram que ao se promover projetos urbanísticos que possibilitem a integração entre ambas os lados do rio e a valorização dos espaços públicos verdes nas margens do rio, se desencadeia um processo de produção do espaço público que endossa a sua função social obtendo maiores relação de cuidado, apropriação e uso pela população. Tais relações motivadas pelo Projeto do Parque Capibaribe refletem inclusive na diminuição da vulnerabilidade social, quando ao invés de remover os moradores de baixa renda, cria ferramentas para que os mesmos se envolvam com efetiva participação frente a decisão de como se daria a intervenção e construção do espaço público da comunidade. As ações desenvolvidas tanto na esfera institucional, quanto na esfera local, visaram a construção do lugar, de forma a possibilitar a capacidade organizacional cidadã para participação ativa na resolução dos problemas da comunidade, promovendo assim o desenvolvimento social e sustentável.

\section{REFERÊNCIAS}

ALENCAR, Anna K.B. Urbanismo sensível às águas: o paradigma da sustentabilidade na concepção de projetos para recuperação de rios urbanos. Tese Recife, 2016. $294 \mathrm{f}$.

CASTRO, J. de. Fatores de localização da cidade do Recife: Um ensaio de geografia urbana. Rio de Janeiro. Casa do Estudante. 1948.

INCITI / UFPE. Relatório INCITI 2016. In:http://wiki.inciti.org/index.php/Relat\%C3\%B3 rio_INCITI_2016.

LIMA, Rosa M. C. A Cidade Autoconstruída. Tese de Doutorado em Planejamento urbano e regional. IPPUR - UFRJ, 2005. 355 p.

MELLO, Sandra. S. de. Espaços Urbanos em beira d'água: Urbanidade e Proteção In: Ordem $e$ Desordem: Arquitetura e Vida Social (Org.) HOLANDA, Frederico, 2012 FRBH Edições.

OBSERVATÓRIO PE. Banco de Dados das ZEIS (BDZEIS). Recife: Observatório PE (UFPE/FASE), ETAPAS, 2005.

FREIRE, J. Urbanismo emergente: ciudad, tecnologa e innovacin social (2009). Disponível em: https://nomada.blogs.com/jfreire/2010/03/urba nismo-emergente-ciudad-tecnologa-e-innovacinsocial.html. Acesso em: 22 ago. 2015.

IBGE - Censo Demográfico - 2010, Disponível em: https://censo2010.ibge.gov.br/resultados.html Acessado em 15 de novembro de 2014.
PARQUE CAPIBARIBE. Parque Capibaribe, caminho das capivaras: Projeto e Plano Preliminar. Primeira Consulta Pública. Recife, 2014.

REIS F. N. G; BUENO, PICCOLOTTO B. S; BRUNA, P. J. V. Imagens de vilas e cidades do Brasil colonial. São Paulo: Editora da Universidade de São Paulo; Imprensa Oficial, 2000.

RECIFE. PREFEITURA DA CIDADE DO RECIFE - Lei Municipal $n^{\circ} 17.511 / 2008$ - Plano Diretor da Cidade do Recife, 2008.

PROJETO RECIFE: Revitalização do rio Capibaribe, URB, Recife, 1979.

_. Projeto Capibaribe Melhor PCR/ Banco Mundial, 2009.

BRASIL. Plano Brasil sem Miséria, para o município do Recife. Disponível em: http://www.brasilsemmiseria.gov.br. Acessado em: 04 de setembro, 2014

BRASIL. Índice de Vulnerabilidade Social. Disponível em: http://aplicacoes.mds.gov.br/sagirmps/idv/ Acessado em 04 setembro 2014.

HORTA COMUNITÁRIA NA VILA DE SANTA LUZIA NA TORRE Disponível em: https://jconlineinteratividade.ne10.uol.com.br/ga leria/2018,11,30,8985,galeria.html Acessado em 12 de dezembro de 2018. 